\title{
Transforming Activities and Base Contents of Deoxyribo- nucleate Preparations from Various Neisseriae
}

\author{
By B. W. CATLIN aNd L. S. CUNNINGHAM \\ Departments of Microbiology and Anatomy, \\ Marquette University School of Medicine, Milwaukee, Wisconsin, U.S.A.
}

(Received 25 March 1961)

\begin{abstract}
SUMMARY
Genetic transformation was investigated among Neisseria spp. whose normal habitat is the nasopharynx of humans. Seven species, as characterized in Bergey's Manual (1957), were represented. Deoxyribonucleate (DNA) preparations from streptomycin-resistant mutants of $N$. meningitidis, N. perflava, N. flava, $N$. subflava, N. sicca, and $N$. flavescens conferred resistance upon streptomycinsusceptible parent strains of the corresponding species (intraspecific transformation) and of each other species (interspecific transformation). Ratios of interspecific to intraspecific transformation were $\mathbf{0 . 0 1}$ or higher for all possible combinations of DNA and recipient cells of the six species. On the other hand, $N$. catarrhalis cells, which exhibited high frequencies of intraspecific transformation, were not transformed at detectable frequencies by DNA from any of the six Neisseria species listed above. In turn, DNA from $N$. catarrhalis had little or no transforming activity for these other neisseriae.

Possible evidence of structural differences between these DNA's was sought by analysing the base contents of transforming preparations. The bases adenine, thymine, guanine and cytosine were present in about equal proportions in the DNA's of the six Neisseria: meningitidis, perflava, flava, subflava, sicca and flavescens. In DNA preparations from two strains of $N$. catarrhalis, however, adenine and thymine predominated. The ratio (adenine + thymine/guanine + cytosine) was higher than $1 \cdot 4$ compared to $1 \cdot 0$ for the others.
\end{abstract}

\section{INTRODUCTION}

Neisseria meningitidis undergoes genetic change (transformation) affecting capsular antigen specificities (Alexander \& Redman, 1953) or response to streptomycin (Catlin, 1960a) following brief exposure to solutions of deoxyribonucleate (DNA). The customary source of DNA is experimentally lysed cells. However, genetically active DNA may be found also in the extracellular environment of $N$. meningitidis (Catlin, 1960a) and $N$. sicca (Catlin, 1960b), presumably owing to spontaneous cellular lysis of some proportion of the populations. DNA can be isolated from the supernatant fluids of centrifuged broth cultures and purified. Moreover, the crude DNA-containing culture slimes themselves elicit transformation. Both $N$. sicca and $N$. meningitidis culture slimes have transforming activity for $N$. meningitidis cells (Catlin, $1960 a, b$ ). 
Extracellular transforming activity has been demonstrated also in cultures of pneumococcus (Ottolenghi \& Hotchkiss, 1960). These findings taken together with the knowledge that transformation can occur in vivo (see Austrian, 1952) give substance to the idea that transformation does occur in nature, and that it may be a regular method of genetic transfer for some bacteria. Some of the consequences for bacteria of genetic recombination have been discussed by Ravin (1960).

A variety of Neisseria spp. inhabit the nasopharyngeal mucosa of man. They may be numerous and proximate in this niche, conditions which should have provided opportunities for recombination, if it occurs. This group appeared favourable, therefore, for investigations of genetic transfer. One or more representatives of each of seven Neisseria species (as characterized in Bergey's Manual, 1957) which inhabit the nasopharynx were examined quantitatively for their capacity to become transformed to streptomycin resistance following exposure to preparations of DNA isolated from streptomycin-resistant mutant strains derived from each of the seven species. In addition, base analyses were carried out on transforming preparations in an attempt to correlate DNA composition with affinities among the Neisseria inferred from the transformation tests; preliminary reports have appeared (Catlin, $1960 c, 1961)$.

\section{METHODS}

Media. Heart infusion broth (Difco) with or without $0 \cdot 3 \%(\mathrm{w} / \mathrm{v})$ yeast extract (Difco) was supplemented after sterilization with $250 \mu \mathrm{g}$. ribonucleic acid (Nutritional Biochemicals Corporation)/ml., 0.00005 M-sodium glutamate and 0.0005 Mcalcium chloride added separately as sterile solutions (Catlin, 1960a). In these media, designated HIY-1 or HI-1, luxuriant growth of all strains was obtained in shaken cultures. HIY- 1 agar was used in all plating procedures. Concentrations of agar (Difco) employed were $1.4 \%(\mathrm{w} / \mathrm{v}$ ) (hard agar) or $0.7 \%(\mathrm{w} / \mathrm{v}$ ) (soft agar).

To eliminate aberrant responses characteristic of surface growth on dry media, agar was freshly poured on the day it was to be streaked. Hard agar bottom layers for assays were dispensed (in volumes of $20 \mathrm{ml} . \pm 0.5 \mathrm{ml}$.) 3-5 days before use, and plates were held at room temperature; when overlaid with inoculated soft agar, surface moisture was negligible.

Capacity to produce acid from carbohydrates was examined by using HIY-1 medium with $1 \%(\mathrm{w} / \mathrm{v})$ agar, phenol red $0.015 \mathrm{mg} . / \mathrm{ml}$., and $0.5 \%(\mathrm{w} / \mathrm{v})$ of either glucose, maltose, fructose, sucrose, mannitol or lactose. For the latter additions filtersterilized $20 \%(\mathrm{w} / \mathrm{v})$ solutions were added aseptically. Media were tubed with a butt and a short slope, and were inoculated by stabbing the deep agar and streaking the surface.

Characterization of strains. Table 1 lists the Neisseria strains investigated, their sources and designations. Strain numbers preceded by Ne were from the culture collection of the department. All strains were Gram-negative cocci, commonly arranged in pairs with adjacent sides flattened. They grew well on HIY-1 agar, and were oxidase- and catalase-positive. Chromogenesis, if any, was essentially characteristic of the species, as given in Bergey's Manual (1957).

None of the strains produced acid from mannitol or lactose; the (control) medium lacking carbohydrate was invariably alkaline. Reactions of the strains in maltose, fructose and sucrose corresponded, with one exception, to descriptions in Bergey's Manual (1957). The exception related to reactions of Neisseria subflava strain 11076. 
The 'species' is characterized as producing acid from glucose and maltose only. Acid was produced from maltose and fructose within 1-2 days, and usually from sucrose after 4-6 days of incubation. Reactions of this strain, as well as strains of several other species (e.g. N. sicca $\mathrm{Ne} 12$ and $N$. flava 4), were irregular in the glucosecontaining medium; acid was either not produced or was produced after a delay, as previously reported (Pelczar \& Doetsch, 1949; Topley and Wilson's Principles, 1955).

All strains were highly susceptible to the antibacterial action of crystalline dihydrostreptomycin sulphate (Squibb). This antibiotic will be referred to as DST, and strains resistant to its action as streptomycin-resistant $(s t r-r)$. Spontaneous singlestep mutations conferring resistance to at least $500 \mu \mathrm{g}$. DST $/ \mathrm{ml}$. were obtained from all seven species, essentially as described (Catlin, 1960a).

Table 1. Sources of Neisseria strains

\begin{tabular}{|c|c|c|c|}
\hline \multicolumn{2}{|c|}{ Designation } & \multirow[b]{2}{*}{ Source } & \multirow{2}{*}{$\begin{array}{c}\text { Year } \\
\text { isolated (i) } \\
\text { or received (r) }\end{array}$} \\
\hline Strain & Species & & \\
\hline Ne 15 & N. meningitidis & $\begin{array}{l}\text { Spinal fluid, fatal, non-epidemic } \\
\text { meningitis }\end{array}$ & 1955 (i) \\
\hline $\mathrm{Ne} 16$ & N. perflava & Throat culture, outpatient & 1957 (i) \\
\hline $\mathrm{Ne} 20$ & N. perflava & Throat culture, outpatient & 1958 (i) \\
\hline 4 & N. flava & University of Maryland Collection* & $1960(r)$ \\
\hline $\mathbf{5 5}$ & N. flava & University of Maryland Collection* & $1960(r)$ \\
\hline JJ IIA & N. flava & $\begin{array}{l}\text { Statens Seruminstitut Collection, } \\
\text { Copenhagen } \dagger\end{array}$ & $1960(\mathrm{r})$ \\
\hline 2104 & N.flava & $\begin{array}{l}\text { Sputum culture, Walter Reed Army } \\
\text { Institute of Research, Washington }\end{array}$ & 1960 (i) \\
\hline 2105 & N. flava & $\begin{array}{l}\text { Sputum culture, Walter Reed Army } \\
\text { Institute of Research, Washington }\end{array}$ & 1960 (i) \\
\hline 11076 & N. subflava & American Type Culture Collection & $1960(r)$ \\
\hline Ne 12 & N. sicca & Throat culture, healthy student & 1954 (i) \\
\hline 13120 & N. flavescens & $\begin{array}{l}\text { American Type Culture Collection, } \\
\text { N.I.H. strain N } 155^{*} \downarrow\end{array}$ & $1960(\mathrm{r})$ \\
\hline Ne 11 & N. catarrhalis & University of Rochester Collection & $1954(r)$ \\
\hline Ne 13 & N. catarrhalis & $\begin{array}{l}\text { New York State Department of Health, } \\
\text { strain } 34105\end{array}$ & $1954(r)$ \\
\hline
\end{tabular}

Organisms were stored at $-60^{\circ}$. A number of similar suspensions of each strain was frozen at one time for subsequent use.

DNA preparations. Streptomycin-resistant strains were subcultured several times on HIY-1 agar supplemented with $500 \mu \mathrm{g}$. DST $/ \mathrm{ml}$. The last subculture served as inoculum for antibiotic-free HIY-1 broth cultures (incubated at $37^{\circ}$ on a shaker) or HIY-1 agar $(2 \%, w / v)$ plates (incubated at $37^{\circ}$ with $70 \%$ humidity). Cultures were harvested after 18-22 hr. Organisms were lysed with sodium dodecylsulphate, as described (Catlin, $1960 \mathrm{a}$ ). The DNA-containing fibrous masses obtained by precipitation with 2 volumes of ethanol were purified by methods (Catlin \& Cunningham, 1958; Catlin, $1960 a$ ) which included two separate steps of deproteinization with sodium dodecylsulphate; each was followed by a step involving centrifugation of the DNA solution (in $\mathrm{M}-\mathrm{NaCl}$ ) for $110 \mathrm{~min} .\left(32,000 \mathrm{~g} ; 3^{\circ}\right)$, and precipitation of DNA fibres with ethanol. The final DNA solutions (in $0 \cdot 14 \mathrm{M}-\mathrm{NaCl}$ ) were prepared using aseptic 
precautions (Catlin, 1960 a), and were found to be sterile. Concentration of DNA was determined by the diphenylamine reaction (Dische, 1955).

Transformation tests. A procedure developed during quantitative transformation studies of Neisseria meningitidis (Catlin, 1960a) was applied uniformly to all Neisseria species. It involved the following steps.

(1) Preparation of suspension of recipient cells. Punctiform surface colonies were picked from HIY-1 agar which had been incubated 11.5-13 hr. in a water-jacketed incubator at $37^{\circ}$. A homogeneous suspension of cells was prepared in warm $\left(36^{\circ}\right)$ HI-1 broth. Occasionally the suspension was coarse, in spite of vigorous repeated expulsion from a pipette; it was centrifuged briefly, and the supernatant fluid was used. Suspensions having a barely visible turbidity contained about $10^{7}$ colonyforming units $/ \mathrm{ml}$. A further dilution was made in warm broth to give the desired population size.

Absence of cellular aggregation, a condition rarely attained with cocci, is essential for an accurate determination of transformation frequencies. Among the Neisseria spp. examined, $N$. meningitidis was exceptional in providing suspensions having usually about $95 \%$ single or paired cocci (Catlin, 1960a). Other species gave suspensions having 5-30\% of aggregates containing 3-8 cells, most of which numbered 3-4. (Strains of N. sicca and N. catarrhalis, which were most troublesome, produced no fewer aggregates in shaken HIY-1 broth cultures). As the same cellular suspension was used for comparisons of different transforming preparations, results were affected equally by aggregation, however, and ratios of interspecific to intraspecific transformation were found to be reproducible.

(2) Exposure to DNA. As soon as the cellular suspension was prepared, $1.5 \mathrm{ml}$. was added to $1.5 \mathrm{ml}$. of each DNA preparation (20.0 $\mu \mathrm{g} . / \mathrm{ml}$. diluted in HI-1 broth). Each reaction mixture (in $25 \times 150 \mathrm{~mm}$. screw-cup tube) was incubated at $36^{\circ}$ for $30 \mathrm{~min}$., whereupon $\mathbf{0 . 0 3} \mathrm{ml}$. of a solution of sterile pancreatic deoxyribonuclease (Worthington) $1 \mathrm{mg} . / \mathrm{ml}$. with magnesium, was added to destroy unbound transforming DNA.

(3) Assay of number of 'cells' $/ \mathrm{ml}$. exposed $=\boldsymbol{E}$. One or more test populations was sampled just after addition of deoxyribonuclease. Measured volumes of appropriate dilutions in HI broth were added to tubes containing $4 \mathrm{ml}$. of HIY-1 soft agar (liquefied and held at $44^{\circ}$ ). These were poured over supporting layers of HIY-1 hard agar. Plates were incubated at $37^{\circ}$ for $2-3$ days. The value $\mathbf{E}$ was calculated from the mean number of colonies on five plates, which usually agreed within $10 \%$.

(4) Assay of number of transformants $/ \mathrm{ml} .=\mathrm{T}$. All reaction mixtures were assayed within $90 \mathrm{~min}$. of initiation of exposure. A sample of $(0 \cdot 1-2 \cdot 0 \mathrm{ml}$.) was mixed with $40 \mathrm{ml}$. of HIY-1 soft agar (at $44^{\circ}$ ); immediately the entire volume was dispensed in $4 \mathrm{ml}$. aliquots on the surfaces of a set of $10 \mathrm{HIY-1}$ hard agar plates. Five min. later the plates were placed without stacking at $37^{\circ}$. Five hr. after the time of initial exposure of cells to DNA, plates were removed to room temperature, and each was overlaid with a 4-ml. top layer of HIY-1 soft agar containing DST in a quantity sufficient to give $500 \mu \mathrm{g}$. DST/ml. after diffusion of the antibiotic through the underlying agar. Plates were left at room temperature for a further $45 \mathrm{~min}$; then they were returned to $37^{\circ}$ and were not stacked until each had warmed uniformly. Colonies were counted after incubation at $37^{\circ}$ for 3-4 days. The oxidase reaction was used to check all colonies on plates having fewer than ten colonies. 
A control reaction mixture containing transforming DNA which had been inactivated by addition of deoxyribonuclease $5 \mathrm{~min}$. before adding recipient cells was included in all transformation tests (Catlin, 1960a). Streptomycin-resistant (mutant) colonies were very rarely found.

Analysis of base contents of transforming $D N A$ preparations. RNA was removed as described by Smith \& Wyatt (1951). After drying from acetone, DNA was hydrolysed as described by Wyatt \& Cohen (1953), using test tubes called ignition tubes in the U.S.A. (There is danger of the tubes exploding during or after heating.) Bases were then determined as described by Wyatt (1951) except that the differential extinction method (Vischer \& Chargaff, 1948) was used, the coefficients being given by Bendich (1957).

Table 2. Transformation of neisseriae by DNA preparations (final concentration $10 \mu \mathrm{g} . \mathrm{DNA} / \mathrm{ml}$.) from streptomycin-resistant strains of the same species

\begin{tabular}{|c|c|c|c|c|c|}
\hline \multicolumn{3}{|c|}{ Streptomycin-susceptible recipients } & \multirow{2}{*}{$\begin{array}{c}\text { Derivation } \\
\text { of DNA } \\
\text { donor }\end{array}$} & \multirow{2}{*}{$\begin{array}{c}\text { Str }-r \\
\text { transformants } \\
\text { No./ml. (T) }\end{array}$} & \multirow[b]{2}{*}{$\frac{\mathbf{T}}{\mathbf{E}} \times 10^{5}$} \\
\hline Species & Strain & $\begin{array}{c}\text { No. } \\
\text { exposed/ml. (E) }\end{array}$ & & & \\
\hline N. meningitidis & $\mathrm{Ne} 15$ & $4.6 \times 10^{6}$ & Ne 15 & $15,700 *$ & $341 \cdot 3$ \\
\hline \multirow[t]{4}{*}{ N. perflava } & $\mathrm{Ne} 16$ & $1 \cdot 1 \times 10^{6}$ & $\mathrm{Ne} 16$ & $17,390^{*}$ & $\mathbf{1 , 5 8 0 \cdot 9}$ \\
\hline & $\mathrm{Ne} 16$ & $1.1 \times 10^{6}$ & $\mathrm{Ne} 20$ & 12,080 & $1,098 \cdot 2$ \\
\hline & $\mathrm{Ne} 20$ & $1.4 \times 10^{6}$ & Ne 16 & 313 & $22 \cdot 4$ \\
\hline & $\mathrm{Ne} 20$ & $1.4 \times 10^{6}$ & $\mathrm{Ne} 20$ & 941 & $67 \cdot 2$ \\
\hline \multirow[t]{5}{*}{ N. flava } & 4 & $1.7 \times 10^{6}$ & 4 & 17,860 & $1,050 \cdot 6$ \\
\hline & 4 & $1.7 \times 10^{6}$ & 2104 & 16,070 & $945 \cdot 3$ \\
\hline & 4 & $1.7 \times 10^{8}$ & 2105 & 13,260 & $780 \cdot 0$ \\
\hline & 4 & $1.7 \times 10^{6}$ & JJ IIA & 7,470 & $439 \cdot 4$ \\
\hline & 4 & $3.4 \times 10^{6}$ & 4 & $10,260 *$ & $301 \cdot 8$ \\
\hline N. subflava & 11076 & $6.5 \times 10^{6}$ & 11076 & $78^{*}$ & $1 \cdot 2$ \\
\hline N. sicca & $\mathrm{Ne} 12$ & $3 \cdot 0 \times 10^{6}$ & $\mathrm{Ne} 12$ & $199 *$ & $6 \cdot 6$ \\
\hline N. flavescens & 13120 & $1 \cdot 1 \times 10^{7}$ & 13120 & $256 *$ & $\mathbf{2} \cdot \mathbf{3}$ \\
\hline \multirow[t]{4}{*}{ N. catarrhalis } & $\mathrm{Ne} 11$ & $8.4 \times 10^{4}$ & $\mathrm{Ne} 11$ & $12,140 *$ & $14,452 \cdot 4$ \\
\hline & $\mathrm{Ne} 11$ & $8.4 \times 10^{4}$ & $\mathrm{Ne} 13$ & 6,610 & $7,869 \cdot 0$ \\
\hline & $\mathrm{Ne} 13$ & $2.0 \times 10^{6}$ & Ne 11 & 95 & $4 \cdot 8$ \\
\hline & $\mathrm{Ne} 13$ & $2.0 \times 10^{6}$ & $\mathrm{Ne} 13$ & $\mathbf{3 3 0}$ & 16.5 \\
\hline
\end{tabular}

\section{RESULTS}

Intraspecific transformation. Representatives of all seven species of Neisseria examined were transformed from streptomycin-susceptibility to streptomycinresistance by DNA extracted from streptomycin-resistant strains of the corresponding species. Table 2 shows transformation ratios obtained for various strains. Ratios were consistently low for the single strains of $N$. subflava, $N$. sicca, and $N$. flavescens examined; between 1 and 10 transformants/100,000 treated cells (colonyforming units) were obtained in repeated tests. In comparison, high transformation ratios were regularly obtained with certain strains of the other four species. Transformation of $N$. catarrhalis strain $\mathrm{Ne} 11$ varied in five independent experiments from about 5 to $15 \%$ of the treated population. In one of these tests assays of both transformants (T) and total exposed cells (E) were carried out on fifteen plates containing an identical inoculum; ten plates were overlaid with DST-containing medium for determination of $\mathrm{T}$, and five plates without overlays were used for 
counts of total colonies (E). Cellular aggregation presumably gave an upward bias to $\mathrm{T} / \mathrm{E}$ values, and contributed to differences between the values found in independent tests of the same recipient. One of the most extreme examples of such a difference is shown in Table 2, N. flava 4.

Various strains of the same species differed considerably in capacity to become transformed, as shown by $\mathrm{T} / \mathrm{E}$ values for Neisseria perflava and $N$. catarrhalis strains (Table 2). Even greater differences were exhibited by the five $N$. flava strains (Table 1). Only strain 4 was transformed at a useful frequency. No transformants were detected in single exploratory tests of strains 55 and JJ II A (T/E $\times 10^{5}$ ratios were less than 0.007 and 0.06 , respectively). Though a few transformants were obtained with strains 2104 and 2105 , ratios were very low $(0.025$ and 0.017$)$. However, DNA preparations obtained from four of these strains (DNA was not prepared from strain 55) were active in eliciting transformation of strain 4 cells (Table 2 ).

Interspecific transformation. Table 3 and those portions of Table 2 marked by an asterisk give results of seven representative experiments, each of which tested recipient cells of a given species with transforming DNA from all seven species. Data marked by an asterisk in Table 2 are numbers of transformants $/ \mathrm{ml}$. obtained in tests of each recipient with homologous DNA; these intraspecific transformation values were compared with the number of transformants $/ \mathrm{ml}$. elicited by heterologous DNA preparations (interspecific transformation) in the same experiment, and results are expressed in Table 3 as ratios of interspecific to intraspecific transformation.

Table 3. Ratios of interspecific to intraspecific transformation among Neisseria $s p p$.

DNA preparations from streptomycin-resistant strains of

\begin{tabular}{|c|c|c|c|c|c|c|c|}
\hline $\begin{array}{l}\text { Recipient } \\
\text { cells }\end{array}$ & $\begin{array}{c}\text { N. meningi- } \\
\text { tidis } \\
(\mathrm{Ne} \mathrm{15})\end{array}$ & $\begin{array}{c}\text { N. perflava } \\
\text { (Ne 16) }\end{array}$ & $\begin{array}{c}\text { N. flava } \\
(4)\end{array}$ & $\begin{array}{c}\text { N. sub- } \\
\text { flava- } \\
(11076)\end{array}$ & $\begin{array}{r}\text { N. sicca } \\
(\mathrm{Ne} \mathrm{12)}\end{array}$ & $\begin{array}{l}\text { N. flave- } \\
\text { scens } \\
(13120)\end{array}$ & $\begin{array}{c}\text { N. catarrh- } \\
\text { alis } \\
(\mathrm{Ne} \mathrm{11)}\end{array}$ \\
\hline $\begin{array}{l}\text { N. meningitidis } \\
(\mathrm{Ne} 15)\end{array}$ & $*$ & 0.091 & 0.054 & 0.022 & 0.036 & 0.047 & $<0.00003$ \\
\hline N. perflava $(\mathrm{Ne} 16)$ & $0 \cdot 119$ & * & 0.655 & $0 \cdot 192$ & $0 \cdot 141$ & $0 \cdot 064$ & $<0.00003$ \\
\hline N. flava (4) & $0 \cdot 312$ & $0 \cdot 735$ & $*$ & $0 \cdot 188$ & $0 \cdot 342$ & 0.142 & $<0.00005$ \\
\hline $\begin{array}{l}\text { N. subflava } \\
\text { (11076) }\end{array}$ & 0.577 & $4 \cdot 680$ & $3 \cdot 949$ & $*$ & $0 \cdot 666$ & $1 \cdot 154$ & $0.006 \uparrow$ \\
\hline N. sicca $(\mathrm{Ne} 12)$ & 0.020 & 0.025 & 0.010 & $0 \cdot 010$ & * & $0 \cdot 020$ & $0.005 \ddagger$ \\
\hline $\begin{array}{l}\text { N. flavescens } \\
(\mathbf{1 3 1 2 0})\end{array}$ & $0 \cdot 180$ & 0.262 & 0.094 & 0.070 & 0.051 & $*$ & $<0.002$ \\
\hline $\begin{array}{l}\text { N. catarrhalis } \\
\text { (Ne 11) }\end{array}$ & $<0.000002 \S$ & $<0.000002 \S$ & $<0.000002 \S$ & $<0.000002 \S$ & $<0.000002 \S$ & $<0.000002 \S$ & $*$ \\
\hline
\end{tabular}

$*=1 \cdot 0$, intraspecific transformation; see corresponding data of Table $2 ; \dagger=1$ streptomycin-resistant colony/ $2 \mathrm{ml}$. sample; $\ddagger=1$ streptomycin-resistant colony $/ \mathrm{ml}$. sample; $\S=$ no transformants found in samples of $3 \cdot 0 \times$ $10^{6}$ colony-forming units $/ \mathrm{ml}$., $14 \%$ transformants being elicited by homologous DNA in the same experiment (Table 2, Ne 11).

Ratios (Table 3 ) were $\mathbf{0} \cdot 01$ or higher for all possible combinations of recipient cells and transforming DNA involving the six Neisseria species: meningitidis, perflava, flava, subflava, sicca, and flavescens; each recipient was examined in three or more independent experiments. The interspecific transformation values for $N$. sicca were based on colony counts ranging from 1 to $5 / \mathrm{ml}$. (as compared with $199 / \mathrm{ml}$. for intra- 
specific transformation (Table 2). Accordingly, their reliability is doubtful, although very similar results were obtained in two other experiments with strain $\mathrm{Ne} 12$.

Transformation was not detected following treatment of Neisseria meningitidis, $N$. perflava (strains Ne 16 and $\mathrm{Ne} 20$ ), $N$. flava, or N. flavescens recipients with DNA preparations from $N$. catarrhalis. Whether the rare streptomycin-resistant colonies found in tests of $N$. subflava and $N$. sicca represented transformants or spontaneous mutants cannot be determined from available data. One of four tests of $N$. subflava and two of three tests of $N$. sicca showed between one and three streptomycinresistant colonies $/ 2 \mathrm{ml}$, where corresponding numbers of cells treated with depolymerized DNA (controls) gave no resistant colonies. It is hoped that genetic tests of strains originating from such colonies will indicate their origin; we are at present inclined to regard them as spontaneous mutants, reversing the view expressed in a preliminary report (Catlin, 1960c).

Recipient cells of Neisseria catarrhalis strains $\mathrm{Ne} 11$ and $\mathrm{Ne}$ 13, examined in five independent experiments, did not undergo interspecific transformation. In one experiment (Ne 11, Table 2) 12,140 transformants/ml. were elicited by treatment with $N$. catarrhalis $\mathrm{DNA}$ of a population of $8 \cdot 4 \times 10^{4}$ colony-forming units $/ \mathrm{ml}$.; in contrast, a higher concentration of the same cellular suspension $\left(3 \cdot 0 \times 10^{6}\right.$ colonyforming units/ml.) gave no transformants following exposure to DNA preparations from each of the other six species (ratios of interspecific to intraspecific transformation less than $0 \cdot 000002$ (Table 3 ).

Base composition of $D N A$ s. The base contents of transforming DNA preparations are given in Table 4. The ratio (adenine + thymine/guanine + cytosine) for Neisseria meningitidis DNA is in agreement with the value (1.00) found by Lee, Wahl \& Barbu (1956) for another strain of the same species.

Table 4. Purine and pyrimidine contents of $D N A$ preparations obtained from streptomycin-resistant strains of Neisseria spp.

Derivation of DNA donor

N. meningitidis ( $\mathrm{Ne} \mathrm{15)}$

N. perflava (Ne 16)

N. perflava (Ne 20)

N. flava (JJ IIA)

N. subflava (11076)

N. sicca ( Ne 12)

N. flavescens (13120)

N. catarrhalis (Ne 11)

N. catarrhalis (Ne 13)

N. catarrhalis (Ne 13 (11 str-r))*

\begin{tabular}{|c|c|c|c|c|}
\hline \multicolumn{4}{|c|}{ Mole/100 mole total bases } & \multirow{2}{*}{$\frac{\mathrm{A}+\mathrm{T}}{\mathrm{G}+\mathbf{C}}$} \\
\hline Guanine & Cytosine & Adenine & Thymine & \\
\hline $25 \cdot 7$ & $25 \cdot 6$ & $23 \cdot 5$ & $25 \cdot 2$ & 0.95 \\
\hline $25 \cdot 4$ & 24.9 & $26 \cdot 0$ & $23 \cdot 8$ & 0.99 \\
\hline $25 \cdot 4$ & $24 \cdot 4$ & $25 \cdot 2$ & $24 \cdot 9$ & $1 \cdot 01$ \\
\hline $25 \cdot 0$ & $24 \cdot 5$ & $25 \cdot 5$ & $25 \cdot 0$ & 1.02 \\
\hline $24 \cdot 1$ & $26 \cdot 4$ & $21 \cdot 9$ & $27 \cdot 6$ & 0.98 \\
\hline $26 \cdot 4$ & $25 \cdot 1$ & $24 \cdot 0$ & $24 \cdot 4$ & 0.94 \\
\hline $25 \cdot 6$ & $24 \cdot 5$ & $23 \cdot 6$ & $26 \cdot 2$ & 0.99 \\
\hline $19 \cdot 9$ & $20 \cdot 8$ & $28 \cdot 6$ & $30 \cdot 6$ & $1 \cdot 45$ \\
\hline $19 \cdot 1$ & $21 \cdot 0$ & $27 \cdot 9$ & $32 \cdot 1$ & 1.50 \\
\hline $19 \cdot 9$ & $21 \cdot 4$ & $28 \cdot 2$ & $30 \cdot 5$ & $1 \cdot 42$ \\
\hline
\end{tabular}

* Streptomycin-resistant strain derived from Ne 13 by transformation with DNA from Ne 11 str-r.

\section{DISCUSSION}

The near-identity of the base ratios of DNA preparations from six different Neisseria spp.: meningitidis, perflava, flava, subflava, sicca, and flavescens (Table 4) is in accordance with expectation based on the results of transformation experiments. These DNA preparations elicited genetic change of recipient cells in all 
thirty-six possible combinations involving the six kinds of Neisseria (Table 3). Thus, representatives of these six species (as defined in Bergey's Manual, 1957) may be regarded as members of a single group (group 1) in so far as they are related by the possibility of genetic transfer. On the other hand, a barrier to the transfer of genetic information appears to exist between group 1 strains and strains of $N$. catarrhalis. Recipient cells of the latter were not transformed by DNA preparations from group 1 strains, and conversely, DNA from $N$. catarrhalis had little or no transforming activity for recipient cells of group 1 . The significant difference between the DNA base ratios of members of group 1 on the one hand, and $N$. catarrhalis on the other, indicates a possible structural basis for the barrier between the two groups.

A growing body of information suggests that genetic transfer occurs only between bacteria having DNA with similar base ratios (see discussions of this subject by Lanni, 1960, and by Ravin, 1960). Base ratios may range at least from $0 \cdot 4$ to $2 \cdot 7$, as shown by an investigation of the DNA of 60 strains of true bacteria (Lee et al. 1956). A significant difference between ratios found for any two strains implies remoteness of relationship; accordingly, transfer of genetic information between the two would not be expected. Although there is no agreement concerning the scope of the bacterial genus, the inclusion of catarrhalis strains in the genus Neisseria appears illogical from the evolutionary point of view.

In general, where adequate quantitative experimental design has eliminated bias due to differential selection of either the transformed or untransformed elements of the bacterial population, higher frequencies are obtained in intraspecific than in interspecific transformation tests (Schaeffer, 1958; but see Bracco, Krauss, Roe \& MacLeod, 1957). Leidy, Hahn \& Alexander $(1956,1959)$ have applied an analysis of ratios of interspecific to intraspecific transformation to the taxonomy of the genus Haemophilus on the premise that such ratios reflect the degree of relationship of donor and recipient cells. Thus far, however, quantitative investigations of interspecific transformations have been restricted to streptomycin resistance; in view of findings by Green (1959) interpretation of interspecific transformation data involving this single characteristic should be made with caution. He showed that heterogeneity of recipient pneumococcus strains may have an unequal influence on transformation frequencies determined for two different characteristics. The frequency of transformation to streptomycin resistance was consistently lower with one recipient than with a second, whereas these two pneumococcal strains exhibited equal frequencies of transformation to erythromycin resistance following exposure to a single doubly-marked transforming preparation.

The status of several species of Neisseria described in Bergey's Manual (1957) is doubtful. The Subcommittee on the family Neisseriaceae (1954) recognized the need to clarify the classification of all members of the Neisseriaceae. Topley and Wilson's Principles (1955) prefers to recognize as separate species among the Gramnegative cocci of the human nasopharynx only $N$. meningitidis, $N$. flavescens and $N$. catarrhalis; the remaining types, with the possible exception of $N$. sicca, would be combined into a single species, $N$. pharyngis. This suggestion that $N$. perflava, $N$. flava, and $N$. subflava are not sufficiently distinct to warrant separate species designations is in harmony with the present evidence from transformation tests.

DNA preparations from strains of Neisseria flava isolated in areas of the world as distant as the United States and Denmark (Table 1) and at times separated by 
more than 25 years were capable of conveying genetic information to $N$. flava strain 4 (Table 2). However, the latter was transformed by DNA from strain JJ IIA $s t r-r$ at frequencies lower than those elicited in the same experiment by DNA preparations from $N$. perflava (both strains $\mathrm{Ne} 16$ str-r and $\mathrm{Ne} 20$ str-r).

The response of Neisseria subflava strain 11076 was unique among the Neisseria spp. investigated. Recipient cells were transformed at higher frequencies by DNA preparations from streptomycin-resistant strains of $N$. perflava and $N$. flava than by DNA from $N$. subflava str-r. Further study may show that the response of this strain to homologous DNA is an example of 'depressed' transfer of the streptomycin resistance marker (Green; 1959). The atypical fermentation reactions (see 'Methods') suggest that this strain is not a representative of $N$. subflava. Strains which do correspond to the description of $N$. subflava (as given in Bergey's Manual, 1957) are rarely encountered (report of the Subcommittee on the family Neisseriaceae, 1954). A genetic study of available strains, together with further investigations of strain 11076 and representatives of $N$. flava and $N$. perflava, may clarify their taxonomic relations. Further discussion of possible taxonomic implications of ratios of interspecific to intraspecific transformation is better postponed until results of tests with other markers are available.

We are grateful to the following investigators for gifts of Neisseria strains: Dr Frits Ørskov, Statens Seruminstitut, Copenhagen; Dr Michael J. Pelczar, Jr., University of Maryland; Miss Sylvia G. Cary, Walter Reed Army Institute of Research, Washington, D.C., U.S.A. This investigation was supported by research grants E-2353 and C-2128 from the National Institutes of Health, U.S. Public Health Service.

\section{REFERENCES}

Alexander, H. E. \& Redman, W. (1953). Transformation of type specificity of meningococci. J. exp. Med. 97, 797.

Austrian, R. (1952). Observations on the transformation of pneumococcus in vivo. Johns Hopk. Hosp. Bull. $91,189$.

Bendich, A. (1957). Methods for characterization of nucleic acids by base composition. In Methods in Enzymology. Ed. by S. P. Colowick and N. C. Kaplan. Vol. 3, p. 715. New York: Academic Press Inc.

Bergey's Manual of Determinative Bacteriology (1957). 7th ed. Ed. by R. S. Breed, E. G. D. Murray \& N. R. Sмiтh. Baltimore: The Williams and Wilkins Co.

Bracco, R. M., Krauss, M. R., Roe, A. S. \& MacLeod, C. M. (1957). Transformation reactions between pneumococcus and three strains of streptococci. J. exp. Med. 106, 247.

Branham, S. E. (1930). A new meningococcus-like organism (Neisseria flavescens n.sp.) from epidemic meningitis. Publ. Hlth Rep., Wash. 45, 845.

Catlin, B. W. (1960a). 'Transformation of Neisseria meningitidis by deoxyribonucleates from cells and from culture slime. J. Bact. 79, 579.

Catlin, B. W. $(1960 \mathrm{~b})$. Interspecific transformation of Neisseria by culture slime containing deoxyribonucleate. Science, 131, 608.

CATLIN, B. W. $(1960 c)$. Transformation reactions within and between species of Neisseria. Bact. Proc. p. 74.

CAtlin, B. W. (1961). Affinities among Neisseria as revealed by studies of DNAs and DNases. Bact. Proc. p. 90.

Catlin, B. W. \& Cunningham, L. S. (1958). Studies of extracellular and intracellular bacterial deoxyribonucleic acids. J. gen. Microbiol. 19, 522. 
Drsche, Z. (1955). Color reactions of nucleic acid components. In The Nucleic Acids. Ed. by E. Chargaff and J. N. Davidson. Vol. 1, p. 285. New York: Academic Press Inc.

Green, D. M. (1959). A host-specific variation affecting relative frequency of transformation of two markers in pneumococcus. Exp. Cell Res. 18, 466.

HaJek, J. P., Pelczar, M. J. \& Faber, J. E. (1950). Variations in the fermentative capacity of neisseriae. Amer. J. clin. Path. 20, 630.

Jessen, J. (1934). Studien über gramnegative Kokken. Zbl. Bakt. Abt. 1, 133, 75.

LANNI, F. (1960). Genetic significance of microbial DNA composition. Perspectives in Biol. Med. 3, 418.

LEe, K. Y., WAHL, R. \& BARBU, E. (1956). Contenu en bases puriques et pyrimidiques des acides désoxyribonucléiques des bactéries. Ann. Inst. Pasteur, 91, 212.

Leidy, G., Hahn, E. \& Alexander, H. E. (1956). On the specificity of the desoxyribonucleic acid which induces streptomycin resistance in Hemophilus. J. exp. Med. 104, 305.

Leidy, G., Hahn, E. \& Alexander, H. E. (1959). Interspecific transformation in Hemophilus; a possible index of relationship between $H$. influenzae and H. aegyptius. Proc. Soc. exp. Biol., N.Y. 102, 86.

Ottolenghi, E. \& Hotchkiss, R. D. (1960). Appearance of genetic transforming activity in pneumococcal cultures. Science, 132, 1257.

Pelczar, M. J. \& Doetsch, R. N. (1949). On the direct fermentation of maltose. Science, 110, 256.

Ravin, A. W. (1960). The origin of bacterial species. Genetic recombination and factors limiting it between bacterial populations. Bact. Rev. 24, 201.

Schaeffer, P. (1958). Interspecific reactions in bacterial transformation. Symp. Soc. exp. Biol. 12, 60.

Smith, J. D. \& Wyatr, G. R. (1951). The composition of some microbial deoxypentose nucleic acids. Biochem. $J .49,144$.

Subcommitee on the family Neisseriaceae (1954). Preliminary report. Int. Bull. bact. Nomen. Taxon. 4, 95.

Topley and Wilson's Principles of Bacteriology and Immunity (1955). Ed. G. S. WiLson, \& A. A. Mrues, p. 627. Baltimore: The Williams and Wilkins Co.

Vischer, E. \& ChargafF, E. (1948). The separation and quantitative estimation of purines and pyrimidines in minute amounts. J. biol. Chem. 176, 703.

Wyatr, G. R. (1951). The purine and pyrimidine composition of deoxypentose-nucleic acids. Biochem. $J .48,584$.

Wyatr, G. R. \& Conen, S. S. (1953). The bases of the nucleic acids of some bacterial and animal viruses: the occurrence of 5-hydroxymethylcytosine. Biochem. J. 55, 774. 